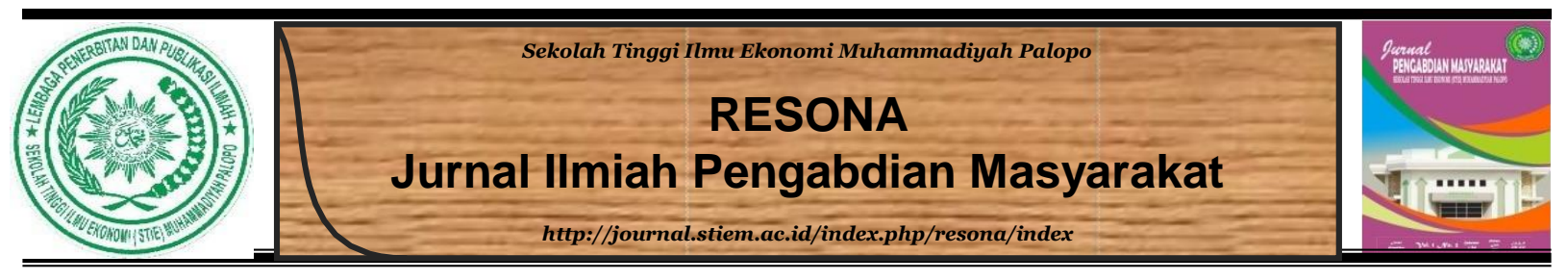

\title{
Pelatihan Penggunaan Metode Wordwall Untuk Meningkatkan Kosa Kata Siswa Di Desa Cenning Kecamatan Malangke Barat Kabupaten Luwu Utara
}

${ }^{1}$ Puspa sari, ${ }^{2}$ harmita sari

STIE Muhammadiyah Palopo

\begin{tabular}{l} 
INFO NASKAH \\
\hline Diserahkan \\
23 maret 2018 \\
Diterima \\
29 mei 2018 \\
Diterima dan Disetujui \\
18 Juni 2018 \\
\hline
\end{tabular}

Kata Kunci:

Wordwall,

Kosa Kata

\begin{abstract}
ABSTRAK
Penguasaan bahasa inggris bagi siswa saat ini telah menjadi suatu hal yang sangat diharapkan. Namun, berdasarkan perkembangan yang ada, para siswa kerap mendapatkan kesulitan dalam proses pembelajarannya. Salah satu metode yang dapat mengatasi hal ini adalah Metode Wordwall. Metode ini dapat digunakan meningkatkan penguasaan kosa kata bahasa inggris. Program pelatihan ini dilakukan di Desa Cenning, Kecamatan Malangke Barat, Kabupaten Luwu Utara. Diikuti oleh para siswa SMP dan SMA di lingkungan desa tersebut. Pelatihan ini mendapatkan respon yang baik dan dengan hasil yang positif pula. Namun demikian, harus tetpa dilakukan pengulangan agar metode ini tetap berjalan dan mendapatkan hasil yang baik di masa depan.
\end{abstract}




\section{Pendahuluan}

Bahasa inggris telah menjadi bagian pembelajaran siswa saat ini baik disekolah maupun diluar sekolah. Dipacu oleh kamajuan teknologi membuat paparan terhadap bahasa inggris lebih mudah terjadi. Namun, banyak pula dari siswa tersebut yang masih merasa kesulitan dalam memahami bahasa inggris. Lubis (2017) dalam penelitiannya menyatakan bahwa beberapa faktor menyebab kesulitan yang dialami mahasiswa dalam menyelesaikan tugas Daily English Conversation adalah kurangnya kedisiplinan dalam berlatih bahasa inggris dan juga kurangnya motivasi.

Allen dan Valette (1977) juga menyatakan bahwa salah satu faktor pendukung dalam mempelajari bahasa adalah penguasaan kosa kata. Hal ini berkaitan erat dengan proses pembelajaran bahasa itu sendiri. Salah satu cara yang dapat digunakan untuk meningkatkan kemampuan kemampuan berbahas adalah dengan penguasaan kosa kata. Saat ini para siswa sekolah medapatkan pengaruh yang besar dari lingkungannya. Baik pengaruh yang positif maupun pengaruh negative. Pembelajaran bahasa harus dapat bisa menyesuaikan dengan lingkungan perkembangan anak saat ini. Salah satu cara yang dapat ditempuh adalah dengan menggunakan metode yang aktif dan interaktif dalam pembelajaran bahasa mereka.

program pelatihan yang diangkat dalam pelatihan ini adalah Wordwall. Metode ini menerapkan cara pembelajaran yang interaktif sehingga para siswa dapat dengan mudah mengikuti program pelatihan ini dan mengembangkannya. Metode ini juga mendorong para siswa untuk dapat selalu berpikir aktif dan kreatif.

\section{Masalah}

Penguasaan kosa kata berperan besar terhadap pembelajaran bahasa inggris. Salah satu cara yang dapat dilakukan untuk meningkatkan penguasaan bahasa inggris pada siswa di desa Cenning Kecamatan Malangke Barat Kabupaten Luwu Utara adalah dengan menggunakan metode Wordwall. Berkaitan dengan hal tersebut perlu dilakukan pelatihan penggunaan metode Wordwall kepada para siswa di daerah tersebut.

\section{Metode}

Pendekatan persuasif digunakan dalam kegiatan palatihan ini dengan menekankan pada metode diskusi dan praktek. Tujuan pebdekatan ini adalah untk meningkatkan kemampuan pemahaman bahasa ingris dan pengoptimalisasian metode pendekatan Wordwall untuk meningkatkan penguasaan kosa kata bahasa inggris. 
Lokasi kegiatan pelatihan ini adalah Desa Cenning Kecamatan Malangke Barat, Kabupaten Luwu Utara. Kegiatan ini dilakukan sebanyak 4 kali yang bertempat di balai kantor Desa Cenning.

\section{Hasil dan Pembahasan}

a. Data peserta

Pelatihan ini diikuti oleh 32 orang siswa yang bertempat tinggal di desa cenning. Peserta pelatihan terdiri dari siswa SMP dab SMA.

Table 1. Data peserta pelatihan

\begin{tabular}{ccc}
\hline No & Jenjang & Jumlah \\
\hline $\mathbf{1}$ & SMP & 19 \\
$\mathbf{2}$ & SMA & 13 \\
& Jumlah Peserta Pelatihan & 32 \\
\hline
\end{tabular}

Setelah observasi awal siswa SD tidak dmasukkan dalam kelompok pelatihan ini, hal ini karena mereka masih mengalami masalah dalam memahami bahasa Indonesia dan Bahasa Inggris. Tidak masuknya bahasa inggris dalam kurikulum sekolah juga menjadi faktor tidak dimasukkannya siswa SD dalam pelatihan ini.

Tabel 2. Tahapan Pelaksanaan Kegiatan

\begin{tabular}{cc}
\hline Urutan & Tahapan Kegiatan \\
\hline I & Survey lokasi \\
II & Penyusunan tahapan pelaksanaan \\
III & .oordinasi dengan pemerintahan desa \\
IV & Pengumpulan peserta \\
V & Pelaksanaan \\
VI & Penyusunan laporan \\
\hline
\end{tabular}

b. Pelaksanaan Kegiatan Pelatihan

Penggunaan metode ini dimaksudkan untuk menguasai kosa kata melalui topik-topik yang ditentukan sebelumnya. Pada setiap sesi, peserta pelatihan akan membahas tentang topic tertentu lalu menentukan kosa kata bahasa inggris yang belum diketahui 
berkaitan dengan topic tersebut. Kosa kata tersebut akan dituliskan dalam sebuah kertas dan akan ditempelkan di dinding. Peserta akan melakukan penguatan terhadap kosa kata tersebut melalui percakapan, permainan dan juga diskusi.

c. Tantangan

Terdapat beberapa tantangan selama pelatihan ini berlangsung, dua diantaranya adalah peserta pelatihan cenderung melupakan materi dan kosa kata setelah pelatihan dan peserta pelatihan menganggap bahwa kertas-kertas berisi kosa kata ini sebagai catatan biasa.

\section{Simpulan dan Saran}

Selama pelatihan ini berlangsungm peserta pelatihan menanggapi pelatihan ini dengan positif. Ditambah lagi respon yang baik ditunjukkan pula oleh pihak keluarga dan sekolah di lingkungan tersebut. Metode ini memudahkan para siswa untuk dapat menguasai kosa kata baru guna meningkatkan kemampuan bahasa inggris para siswa. Kemudahan dalam melakukan metode Wordwall juga memudahkan para siswa untuk menhembangna kemampuan bahasa mereka. Namun, diharapkan kepada orang tua dan guru di sekolah untuk tetap mengingatkan hal ini kepada peserta pelatihan. Peran aktif yang diharapkan dari lingkungan keluarga adalah tetap aktifnya penggunaan wordwall ini di rumah. Salah satunya cara adalah dengan meletakkan catatan wordwall di dinding rumah serta selalu melakukan pembaharuan kosa kata yang dipakai. Sedangkan, bagi pihak sekolah diharapkan untuk mengembangkan Wordwall ini di tempat-tempat dimana siswa sering berkumpul. Kunci keberhasilan metode ini adalah pengulangan oleh karena itu peserta pelatihan diharapkan untuk tetap melakukan metode ini secara simultan.

\section{Ucapan Terima Kasih}

Selama persiapan dan penyelesaian program pelatihan ini ditemui beberapa kendala. Namun kendala ini dapat tertangani dengan atas pertolongan Allah SWT dan juga bantuan dari pihak LPPM (Lembaga Penelitian dan Pengabdian Masyarakat) Universitas Muhammadiyah Palopo, aparat Desa Cenning dan juga masyarakat Desa Cenning. Atas dukungan pihak-pihak tersebut, kegiatan pelatihan ini dapat terselenggarakan dengan baik tanpa halangan yang berarti. 


\section{Daftar Pustaka}

Allen, E. Vallete, R. (1977). Classroom Technique: Foreign Language And English As A Second Language. Harcourt Brace Jovanorich Publisher. San Diego

Lubis, T. (2017). Faktor Yang Mempengaruhi Kesulitan Mahasiswa Dalam Menyelesaikan Daily English Vocabulary. Jurnal Bisnis Administrasi. Vol 6 